\title{
Improving Climate Change Awareness of Preservice Teachers (PSTs) through a University Science Learning Environment
}

\author{
Jin Su Jeong *(D), David González-Gómez (D), María Carmen Conde-Núñez, José Samuel Sánchez-Cepeda \\ and Félix Yllana-Prieto (D)
}

Citation: Jeong, J.S.; González-Gómez,

D.; Conde-Núñez, M.C.;

Sánchez-Cepeda, J.S.; Yllana-Prieto, F. Improving Climate Change Awareness of Preservice Teachers (PSTs) through a University Science Learning Environment. Educ. Sci. 2021, 11, 78. https://doi.org/ 10.3390/educsci11020078

Academic Editor: Eila Jeronen

Received: 14 December 2020

Accepted: 4 February 2021

Published: 18 February 2021

Publisher's Note: MDPI stays neutral with regard to jurisdictional claims in published maps and institutional affiliations.

Copyright: (C) 2021 by the authors Licensee MDPI, Basel, Switzerland. This article is an open access article distributed under the terms and conditions of the Creative Commons Attribution (CC BY) license (https:// creativecommons.org/licenses/by/ $4.0 /)$.
Departamento de Didáctica de las Ciencias Experimentales y Matemáticas, Universidad de Extremadura, 10003 Cáceres, Spain; dggomez@unex.es (D.G.-G.); cconde@unex.es (M.C.C.-N.); samuel@unex.es (J.S.S.-C.); feyllanap@unex.es (F.Y.-P.)

* Correspondence: jin@unex.es

Abstract: The position of universities is of great importance in climate change education (CCE) if the scientific, environmental, social, and political challenges the world confronts are to be met. It is, therefore, crucial to comprehend the CCE being engaged in globally by higher education institutions (HEIs). It is also important to discover and analyze the ways that HEIs can better address this challenge. Consistent with the requirements of research, this study offers an analysis of climate change awareness-raising of preservice teachers (PSTs) in a university science classroom with a flipped class intervention. A total of 109 students participated in this research: 55 students in the control group (Group 1) and 54 students in the experimental group (Group 2). A questionnaire was used to detect any significant difference in the students' awareness of climate change for the two groups and before and after course completion. The analyzed results exposed the improved awareness of climate change in PSTs after a flipped class intervention, and, therefore, PSTs were more willing to engage in climate change teaching. Hence, the results of this study will contribute significantly to reducing existing drawbacks, which will be vital to comprehend the professional teaching developments of preservice teachers. Thus, this research can offer various instances of clarifying how climate change education may be placed in a higher science education context with certain adaptations.

Keywords: climate change; flipped classroom; science education; class intervention; teacher trainee; university education

\section{Introduction}

For over a decade, the Education for Sustainable Development (ESD) program of the United Nations Educational, Scientific, and Cultural Organization (UNESCO) and the United Nations (UN) have played prominent roles in promoting sustainable education [1-3]. In this context, universities and higher education institutions (HEIs) are of great importance in climate change education (CCE) [4-7]. However, education investigation should be fostered to improve the resolutions for climate change mitigation and adaptation to ensure that both instructors and students are involved in the challenges confronted $[8,9]$. Teaching climate change in science education is a concern that continuously draws attention in many studies [10-12]. Instructors need to find new teaching methods (including in climate change education) that can increase their students' learning process $[7,8]$. With the methodology of a flipped classroom, normal learning is changed by taking the lectures, along with the concepts learned in class, out of the classroom through the use of learning activities [8,13]. The flipped classroom, as an active instruction methodology, can be an alternative instruction method to endorse the concept and contents of climate change in university science education $[8,13,14]$. The various written, auditory, and visual materials in flipped instruction methodology can help students learn a subject [15-17]. Thus, learning theorists claim that instructional methods such as the inverted classroom can make it 
possible for students to gain information and knowledge better than through the traditional classroom method [18-20]. In the context of climate change education, at the university level, student awareness has been aided by applying flipped-classroom intervention-based instruction methodology [21]. In fact, numerous studies have shown that it is necessary to further research the appropriate awareness-raising of students of climate change in the context of university education by means of innovative exercises as class activities [22,23].

The objective of this paper is to examine the raising of climate change awareness of preservice teachers (PSTs) in a university science classroom with active and flipped learning environments. A total of 109 students in two groups (Group 1, with 55 PSTs as the control group; Group 2, with 54 PSTs as the experimental group) participated in the course in the context of pre- and post-test surveys. The hypotheses stated in this research are listed as follows:

Hypothesis 1. It is expected that the active flipped intervention would have a positive and affirmative effect on climate change awareness-raising through a university science learning environment.

Hypothesis 2. It is expected that the active flipped intervention would have a more positive and affirmative effect on climate change awareness-raising than the traditional intervention through a university science learning environment.

Hypothesis 3. It is expected that the active flipped intervention would have a positive and affirmative effect on PSTs' climate change awareness.

\section{Theoretical Framework}

\subsection{Climate Change and Sustainability in Higher Education}

As an obvious phenomenon in the world, climate change is closely related to human development, growth, and consumption patterns and threatens land use, development, people, and the environment $[1,2,24]$. Spain is among the most vulnerable countries to climate change in the European Union (EU) [2,3]. Therefore, there is a need to foster sustainable education aims, values, and standards on the basis of the ESD program of the United Nations Educational, Scientific, and Cultural Organization (UNESCO). This program has stimulated public and communal consciousness, pursued the development of life-long climate change education, and increased its significance in various learning fields [25-27]. HEIs are contiguously recognized as essential drivers for sustainable societies and climate change education and development [28-31]. Additionally, the positions of universities are of great importance in CCE if the scientific, environmental, social, and political challenges the world confronts are to be met $[4,9]$. It is, therefore, crucial to comprehend the CCE strategies being engaged in globally by HEIs and to discover and analyze the ways that HEIs can better address this challenge $[5,6,28]$. Until now, the investment in CCE has not satisfied the existing requirement despite the acknowledgment that it has been established as an international policy standard [29,32,33]. Higher education organizations are required to ensure that both instructors and students are involved with the challenges confronted [30]. Thus, it is necessary to encourage investigation, to improve the resolutions for climate change mitigation and adaptation, and to create a prominent role in public and open address [33,34]. Currently, substantial first steps have been managed at many higher institutions, but many challenges and difficulties still remain and continue [35-37]. Bushell et al., (2017) mentioned the action gap, which describes the changed scale that can give attention to educators [24,38]. In these challenging and opposing circumstances, climate change in university science education offers to fill the pedagogical niche and gap and explore how climate change awareness-raising of PSTs are embedding in active learning environments in a life-long cycle $[29,39,40]$. 


\subsection{Flipped Classroom for Teaching Climate Change in University Science Education}

Teaching climate change in university science education is a concern that has continuously drawn the attention of instructors and PSTs in many studies [10-12]. The importance of instruction methodology must focus on climate change in science learning by approving more inquiry-based, student-centered, hands-on, and two-way learning activity scenarios because traditional instruction methodologies have, currently, negative consequences [41,42]. The flipped classroom as an active instruction methodology, introduced by Jonathan Bergmann and Aaron Sams, has gotten attention as an alternative and active instruction method $[8,13,14]$. The foundation of the active flipped classroom should be searched for in social learning theory and constructivism because learning procedures, from the viewpoint of students, are attained as an active and social development [15,43]. The flipped classroom methodology can reverse the normal classroom method by moving the lectures out of the classroom, together with the concepts taught, through the use of various learning activities $[8,13]$. Particularly, it can indorse the concept and contents of climate change in science education that is a special form of blended learning [13,14]. As an agreed premise, this methodology indicates that direct instructional methodology is an effective teaching tool for individuals and not for groups [15,44]. Thus, many scholars claim that instructional methods such as the flipped classroom can contribute to students learning better than with traditional instruction methodology [18-20]. The various written, auditory, and visual materials in flipped instruction methodology can support students in learning a subject, and they can then find out what parts they do not understand $[8,16,17]$. In the class, based on the materials learned, they participate in problem-solving, class intervention, group discussion, and debate within more collaborative, just-in-time lectures and student-centered learning activities [45,46]. Hence, this methodology specifies a more suitable learning environment in terms of raising PSTs' climate change awareness when a flipped classroom methodology is followed in university science education.

\subsection{Raising of Climate Change Awareness in Flipped University Science Education}

The attitude introduced by Fishbien and Ajzen [47] is delineated as a deliberated inclination that can be answered in a continuously favorable or unfavorable approach. In accordance with a certain object given, it is considered a formative feature in predicting a person's performance [21,48]. Thus, many studies have proposed that the influence of attitude activities are reasonably lasting but can also be considered and reviewed $[49,50]$. Along with the instructors' teaching practices, instructors' attitudes concerning climate change have been acknowledged to influence the PSTs' attitudes toward science and science education and, in general, their scientific literacy [49,51]. Moreover, the attitudes of instructors can be associated with his/her instruction ability [51,52]. Consequently, the PSTs' certainty in their ability to give a lecture on climate change in science has been revealed as a significant predictor for their imminent and upcoming instruction practice and exercise [52]. Regarding climate change in university science education, an appropriate and suitable attitude is a necessity for positively embracing active classroom methodology in a science course [21,47]. Due to the aforementioned reasons, understanding PSTs' attitudes concerning climate change in university science education is fundamental in an active course in order to achieve a professional vision and the concentrated improvement of PSTs [53,54]. However, there are not many studies that have researched in-service teachers' nor PSTs' attitudes on this particular subject. Hence, clarifying the PSTs' climate change attitudes has been a substantial challenge in the education of instructors [55]. Accordingly, numerous studies have shown that instructors with appropriate attitudes are much more open to improving instructive situations. They are much keener to introduce novel and innovative exercises to their class [47-49,56,57]. 


\section{Materials and Methods}

\subsection{Sample}

The study was conducted on the subject of "Knowledge of the Natural Environment in Primary Education" for senior-level teachers at the Teaching Training School of the University of Extremadura, Spain. This course aims to provide the PSTs with an overall understanding of scientific content and educational strategies to introduce this scientific content to primary education students. Additionally, it was to educate the PSTs on primary education students. The study was conducted during the first term of the 2019/2020 course, and a total of 109 teacher-trainee students participated in the course. The students were randomly allocated into two groups (control and experimental groups, Group 1 and Group 2, respectively). For Group 1, 55 students were assigned and used as the control group; for Group 2, 54 students were assigned and used as the experimental group. Table 1 summarizes, as descriptive analysis, the main demographic information of the two groups who initially participated in the survey proposed. Both groups had more female students than male students; the participants' average age was 22 years old. The grade point average (GPA) at the beginning of the first semester was 7.7. Only an average of $26.7 \%$ of students, as shown in Table 1, had taken science subjects during their academic formation (middle and high schools). Their place of origin indicated that the PSTs were more from rural areas than cities in both groups. Based on their educational background, most participants for both groups were from social sciences $(72.7 \%$ and $66.7 \%$, respectively). However, although the initial questionnaire (as a pretest survey) was answered and completed by a total of 109 students, only 101 students (54 and 47, respectively; about 92.7\%) answered and fully completed the questionnaires in the post-test survey ( $98.2 \%$ and $87.0 \%$, respectively).

Table 1. Demographic information of the students of the two groups for the research proposed.

\begin{tabular}{|c|c|c|c|}
\hline \multicolumn{2}{|c|}{ Items } & Control Group 1 & Experimental Group 2 \\
\hline \multicolumn{2}{|c|}{$n$} & 55 & 54 \\
\hline \multirow{2}{*}{ Gender (\%) } & Male & 23.6 & 38.9 \\
\hline & Female & 76.4 & 61.1 \\
\hline \multicolumn{2}{|c|}{ Age } & 21.4 & 22.6 \\
\hline \multicolumn{2}{|c|}{ GPA (max. 10) } & 7.7 & 7.7 \\
\hline \multirow{5}{*}{$\begin{array}{c}\text { Educational } \\
\text { Background }(\%)\end{array}$} & Social Sciences & 72.7 & 66.7 \\
\hline & Sciences & 25.5 & 27.8 \\
\hline & Arts & 0.8 & 3.6 \\
\hline & Others (Technologies & & \\
\hline & $\begin{array}{l}\text { and Professional } \\
\text { School) }\end{array}$ & 1.0 & 1.9 \\
\hline \multirow{2}{*}{ Place of Origin (\%) } & City & 47.3 & 44.4 \\
\hline & Rural & 52.7 & 55.6 \\
\hline \multirow{4}{*}{ University Access (\%) } & High School & 96.4 & 92.6 \\
\hline & Professional School & 0 & 3.7 \\
\hline & Test $>25$ & 1.8 & 0 \\
\hline & Others & 1.8 & 3.7 \\
\hline
\end{tabular}

\subsection{Course Context}

As a general course for university science education, the subject is carried out as shown in Table 2. As part of the senior level of the Bachelor of Arts degree, the subject "Knowledge of the Natural Environment in Primary Education" was carried out for the two groups at the Teaching Training School of the University of Extremadura, Spain. 
Table 2. Course context for the subject at a senior level of the 2019/2020 course.

\begin{tabular}{|c|c|c|c|c|}
\hline \multirow{3}{*}{ Chapter } & \multicolumn{4}{|c|}{ Course Context } \\
\hline & \multicolumn{4}{|c|}{ Knowledge of the Natural Environment in Primary Education } \\
\hline & Title & Description & Class Hours & $\begin{array}{l}\text { Flipped } \\
\text { Hours }\end{array}$ \\
\hline 1. & $\begin{array}{l}\text { Current challenges of } \\
\text { primary science education }\end{array}$ & $\begin{array}{l}\text { Science, technology and society, and primary } \\
\text { education. Scientific education and } \\
\text { cross-cutting themes for primary education. } \\
\text { Interdisciplinarity in science teaching-learning } \\
\text { of primary education. }\end{array}$ & 35 & 20 \\
\hline 2. & $\begin{array}{l}\text { Learn to teach science in } \\
\text { primary education through } \\
\text { different strategies }\end{array}$ & $\begin{array}{l}\text { School research, trips to the environment, } \\
\text { problem-solving, practical work, and project } \\
\text { work for primary education. }\end{array}$ & 38 & 20 \\
\hline \multirow[t]{3}{*}{3.} & $\begin{array}{l}\text { Contents of science } \\
\text { education for the primary } \\
\text { education stage }\end{array}$ & $\begin{array}{l}\text { Teaching/learning activities for primary } \\
\text { education: the environment and its } \\
\text { conservation, the diversity of living beings, } \\
\text { health and personal development, matter and } \\
\text { energy, technology, objects, and machines. }\end{array}$ & 75 & 50 \\
\hline & \multicolumn{2}{|r|}{ Evaluation } & 2 & \\
\hline & \multicolumn{2}{|c|}{ Total } & 150 & 90 \\
\hline
\end{tabular}

The subject consisted of 6 ECTS credits (equivalent to $150 \mathrm{~h}$ ), distributed in $3 \mathrm{~h} /$ week of theoretical classes and $1 \mathrm{~h}$ /week of laboratory session for 15 weeks (January to May). In order to make lab sessions more effective, the PSTs were divided into three groups to attend lab in three different hours. Table 2 shows that the course syllabus was prepared in detail for the suggested course. Firstly, as a core course in the degree program, "Knowledge of the Natural Environment in Primary Education" included science teaching/learning, together with sustainability and climate change value, theory, and its problem-solving and practical work. This course aims to provide the PSTs with an overall understanding of scientific content and educational strategies to introduce the scientific content to primary education students.

The instruction methodology used in the experimental class group (G2) was an active and flipped classroom methodology with class interventions. It contained dynamic lectures and various activities. Particularly, the flipped materials consisted of videos and other formatted materials based on the syllabus, which PSTs received 1 week before each class. With regard to the time of class, a practical exercise was distributed along with the theoretical materials delivered for more student-centered environments. Problems, reasoning, and activities that were ill-defined, rule-based, case-based, and problem-based were among the activities implemented in the classroom. The PSTs' collaboration was always encouraged, and the instructors offered support, together with explanations and lectures in all cases. In both groups, the students had the same content and instructors; therefore, it was possible to track each PST's independent advancement based on the different intervention methodology (see Table 2). Finally, in order to identify the PSTs' learning difficulties, additional online questionnaires and quizzes were made available to students.

\subsection{Instruments}

Various types of questionnaires were used to collect PSTs' information and data. Online survey questionnaires were distributed using Google Forms to the PSTs before and after course completion. When the course had started and was about to finish, the forms were distributed, completed by the PSTs, and collected before and after the class intervention and implication. To guarantee the highest participation rate possible, the PSTs finished the survey in a session of class. Furthermore, the PSTs were asked to complete basic information about demographic aspects such as gender, age, GPA at the beginning of the first semester, educational background, place of origin, and university access. 
The questionnaires were adapted from Roach [58], with multiple selection, multiplechoice, and open-ended answers. The questionnaire followed a five-point Likert-type scale, with "strongly disagree" (SD), "disagree" (D), "neutral" (N), "agree" (A), and "strongly agree" (SA). The test consisted of 22 open and closed questions where the PSTs could express their awareness towards climate change. The list of questions (Q1-Q22) is summarized in Appendix A. Additionally, participants could provide comments at will. Additionally, at the end of the questionnaires, the PSTs were asked to provide their overall opinion.

\subsection{Data Collection and Analysis}

Participation in this study was entirely voluntary, and no personal data was scripted and recorded for any PST. The PSTs were randomly distributed into Group 1 (as the control group) and Group 2 (as the experimental group) before starting the course. Online survey questionnaires were distributed using Google Forms to the PSTs before and after course completion. In order to encourage the PSTs' contribution, survey questionnaires were completed online during classroom-time. The content analysis was made based on frequency counts. With the help of statistical software (SPSS statistics 22.0), the survey questionnaires' data were processed and analyzed. Here, to distinguish, define, and draw conclusions from the sample data, descriptive analysis was made in a suitable manner [59].

\section{Results and Discussion}

\subsection{Survey Analysis Results}

In order to test the research hypotheses, the results obtained from Group 1 as the control group and Group 2 as the experimental group were statistically compared [60-62]. Firstly, the internal consistency of the instrument was assessed by means of the Cronbach alpha test, being 0.78 for the questionnaire. Hence, it could be determined as having acceptable reliability (more than 0.7) [60]. Secondly, the Kolmogorov-Smirnov normality test indicated that the data collected were normally distributed. As a consequence, the mean values were compared by means of the $t$-test, and when significant differences were found, the size of the effect was calculated (Cohen's $d$ ) [61]. Finally, before comparing the mean values, Levene's test was conducted to determine if both groups presented a homogenous distribution (significant values of 0.856 and 0.218 for Levene's test, respectively, for items Q1 and Q22 in pretest data). Table 3 summarizes the results obtained [63].

Table 3. Comparison of items Q1 and Q22 for Group 1 as the control group and Group 2 as the experimental group and preand post-test results.

\begin{tabular}{|c|c|c|c|c|c|c|c|c|}
\hline & \multicolumn{4}{|c|}{$\begin{array}{l}\text { Q1 * (Climate Change Proposed for Years by the } \\
\text { Community of Scientists Is an Invention to Take } \\
\text { Better Care of the Planet). }\end{array}$} & \multicolumn{4}{|c|}{$\begin{array}{l}\text { Q22* ("The Increase in the Hole in the Ozone } \\
\text { Layer Implies a Climatic Change in the Earth"). }\end{array}$} \\
\hline & $\begin{array}{l}\text { Pretest } \\
\text { (Mean) }\end{array}$ & $\begin{array}{l}\text { Post-Test } \\
\text { (Mean) }\end{array}$ & $\begin{array}{c}t \text {-Test } \\
(p \text {-Value) }\end{array}$ & $\begin{array}{l}\text { Size of } \\
\text { Effect } \\
\text { (Cohen's } d)\end{array}$ & $\begin{array}{l}\text { Pretest } \\
\text { (Mean) }\end{array}$ & $\begin{array}{l}\text { Post-Test } \\
\text { (Mean) }\end{array}$ & $\begin{array}{c}t \text {-Test } \\
(p \text {-Value) }\end{array}$ & $\begin{array}{c}\text { Size of } \\
\text { Effect } \\
\text { (Cohen's } d)\end{array}$ \\
\hline Group 1 & 1.93 & 1.89 & 0.959 & - & 4.71 & 4.52 & 0.119 & - \\
\hline Group 2 & 1.87 & 1.73 & 0.041 & 0.489 & 4.59 & 4.02 & 0.007 & 0.584 \\
\hline$t$-test ( $p$-value) & 0.993 & 0.034 & - & - & 0.242 & 0.002 & - & - \\
\hline $\begin{array}{l}\text { Size of effect } \\
(\text { Cohen's } d)\end{array}$ & - & 0.509 & - & - & - & 0.632 & - & - \\
\hline
\end{tabular}

Note: ${ }^{*}$ Lower score indicates better awareness.

These results indicated that no significant differences were observed between the two groups with regard to pretest data. However, significant differences were observed for these two variables in the post-test results. Considering the information of the same group, similar results were obtained. No significant differences were observed for the control group (Group 1) in the pre- and post-test results $(p=0.959)$, while significantly different values were recorded for the experimental group (Group 2). In these cases, the size of the 
effect was measured by means of Cohen's $d$, observing a medium effect in all cases where significant differences were determined. However, from a gender perspective, we could not find any difference in how the causes and effects of climate change affect women and men differently in this study.

We used the format of a five-point Likert-type scale (according to Harpe [62]) to find out the rising awareness of PSTs of climate change in university science education, using item Q1, as shown in Appendix A. The results indicated that $61.82 \%$ of students in Group 1 (as the control group) disagreed with the statement in the pretest survey, while $66.67 \%$ of students disagreed with the same statement in the post-test survey (see Figure 1). Additionally, Group 2 (as the experimental group) demonstrated the same pattern as Group 1 . Here, Group 1 increased their awareness by $4.85 \%$ (in "strongly disagree"), and Group 2 increased their awareness by $5.40 \%$ (in "strongly disagree"), which indicated that Group 2 had better awareness-rising. Particularly, we could see that the PSTs realized the misconception about climate change that many people have in our society. The PSTs' awareness, however, was changed after the class intervention. This was evident in the percentage increase of Group 2 awareness (as the experimental group) after the application of the proposed methodology (versus Group 1). Therefore, the ideas delivered in this study were noteworthy to analyze the awareness of climate change of the PSTs in an active and flipped classroom.

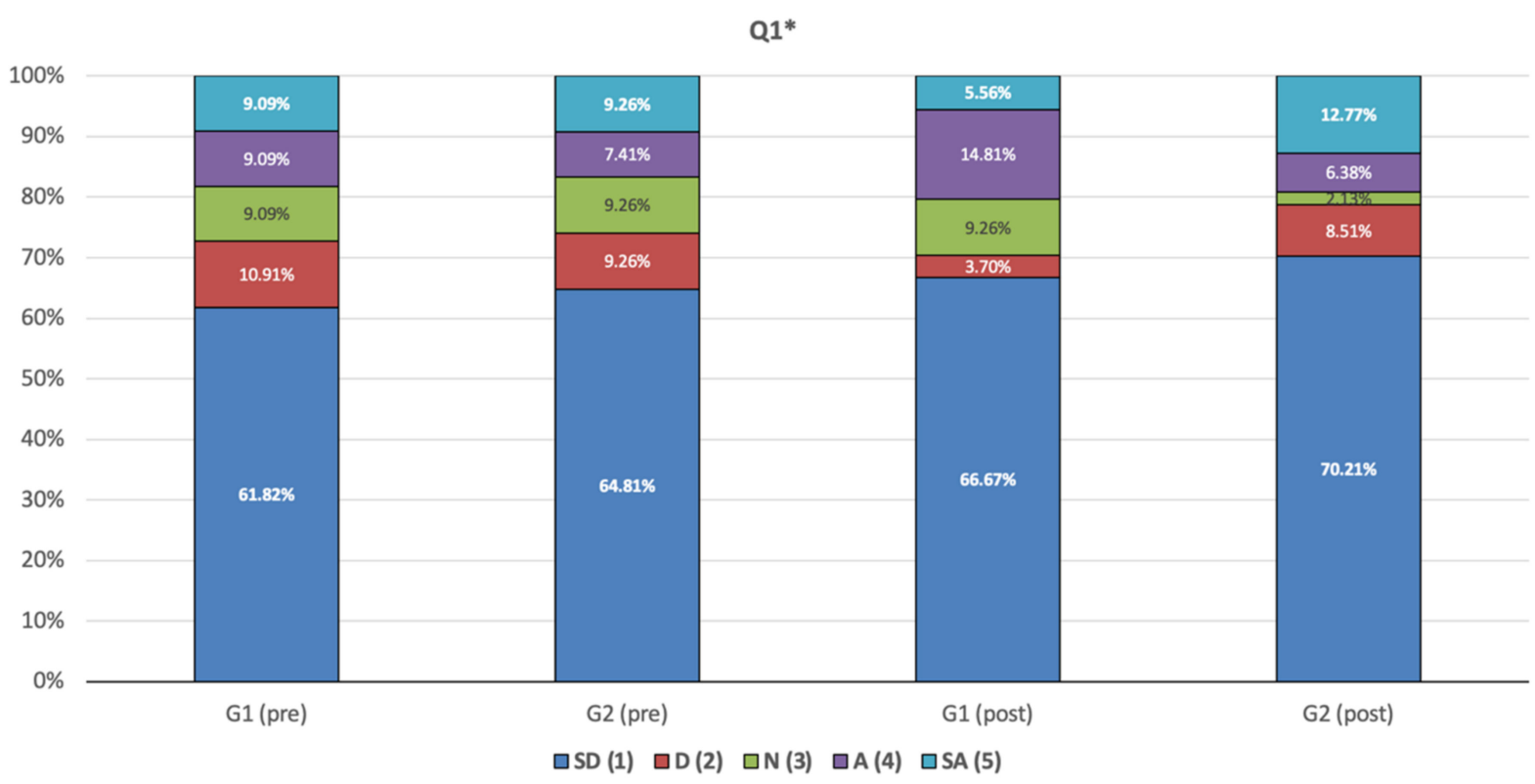

Figure 1. The results of the two groups for item Q1 ("Climate change proposed for years by the community of scientists is an invention to take better care of the planet"), from "strongly disagree" (SD), "disagree" (D), "neutral" (N), "agree" (A), and "strongly agree" (SA). * Lower score indicates better awareness.

Items Q5 and Q11, based on multiple selection and multiple-choice, respectively, were related to the awareness of different types of gas and radiation in climate change. It has a relationship with responsibility, as shown in Appendix A. According to the opinions collected from the PSTs (see Figure 2), for Group 1 as the control group, the results of item Q5 indicated that, in general, the PSTs selected carbon dioxide, methane, and CFCs in the pretest survey and chose the same types of gas, along with ozone (14.55\% increase) in the post-test survey. For the same question, for Group 2 as the experimental group, the PSTs selected carbon dioxide, methane, and CFCs in the pretest survey and chose the same types of gas along with ozone (general decrease without significant change) in the post-test survey. Particularly, an interesting change from Group 2 was found, where the PSTs selected $12.85 \%$ less carbon dioxide compared to Group $1(1.96 \%)$, along with the other gases proposed. It was possible to also observe that the PSTs changed their awareness 
of climate change, which, in our society, many people do not have, after the flipped class intervention. Therefore, the findings present a percentage decrease in scores in the sample that actively participated in the proposed methodology. Furthermore, the ideas delivered in this study were important to analyze the awareness of climate change of the PSTs in an active and flipped classroom.

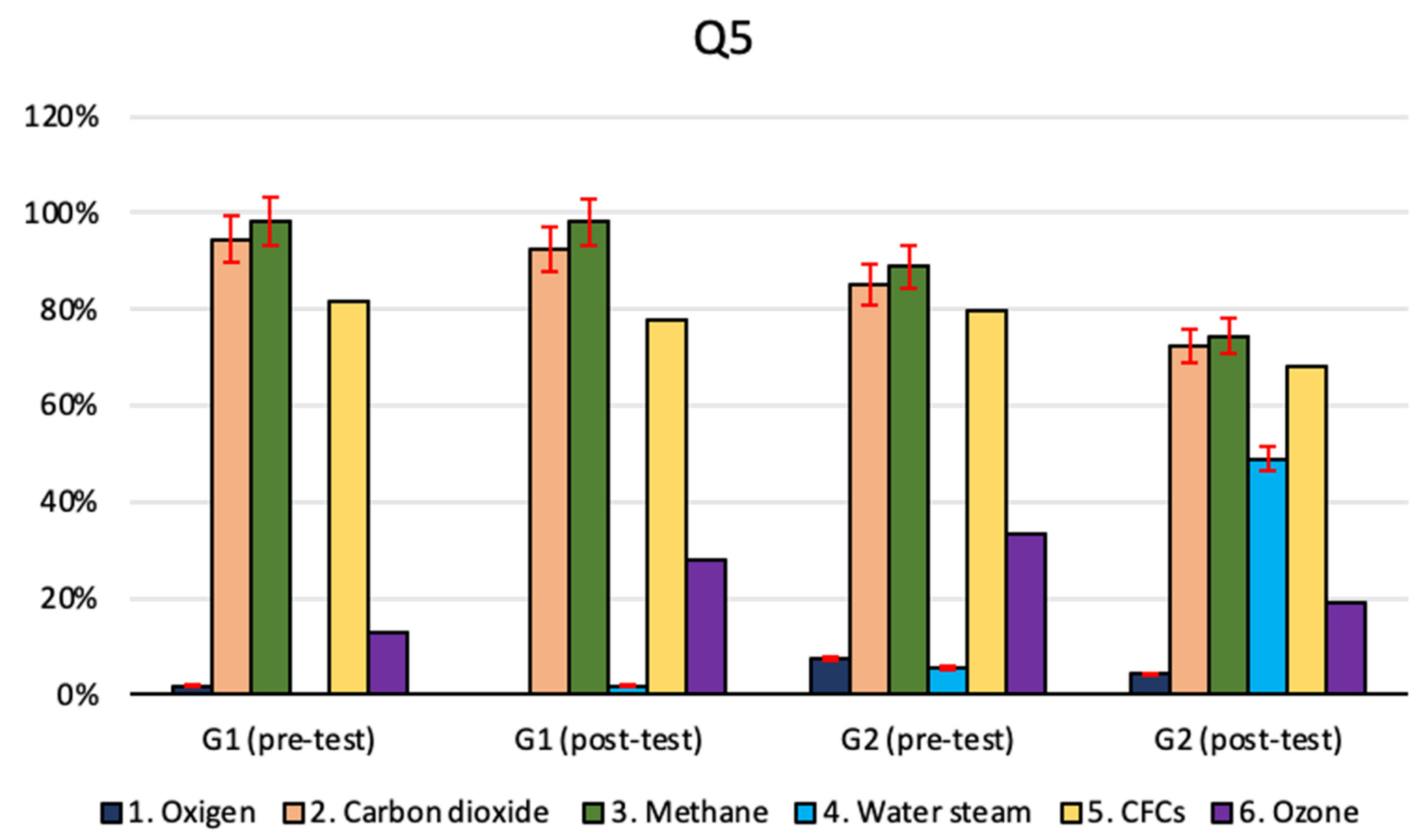

Figure 2. The results of the two groups for item Q5 ("Of the following gases, which one indicates the three most responsible gases for climate change" $)$.

According to the ideas collected from the PSTs (see Figure 3), the results of item Q11 indicated that, in general, for Group 1 as the control group, ultraviolet radiation was selected in the pretest survey, and they chose the same type of radiations, with a $1.59 \%$ increase, in the post-test survey. For Group 2 as the experimental group, the PSTs, for the same question, selected ultraviolet radiation in the pretest survey but chose visible radiation (63.64\% increase), along with $56.50 \%$ less ultraviolet radiation, in the post-test survey. Particularly, we find an interesting change in Group 2. The PSTs selected different radiation types after a class intervention, which could be considered a significant difference. Here, as demonstrated in the questions analyzed, the PSTs changed their awareness about climate change, which many persons in our society do not have, after the class intervention. There was a percentage decrease in scores in the sample through active participation in the flipped methodology. Therefore, in this study, the ideas and opinions dispersed were significant when investigating the awareness of climate change of the PSTs in an active and flipped classroom.

With the format of a five-point Likert-type scale [62], item Q22 was designed to find out the rising awareness of the relationship between the hole in the ozone layer and climate change on Earth, as shown in Appendix A. The questionnaire was graded on the scale of "strongly disagree" to "strongly agree". On the basis of the data gathered from the PSTs, the result indicated that $72.73 \%$ of PSTs in Group 1 (as the control group) agreed with the statement in the pretest survey, while $64.81 \%$ of PSTs agreed with the same statement in the post-test survey (see Figure 4). Additionally, Group 2 (as the experimental group) demonstrated the same pattern. However, while Group 1 decreased by $7.92 \%$ in their awareness-raising, Group 2 decreased by $15.05 \%$ (70.37\% to $55.32 \%$ ) in their awarenessraising. It was possible that the PSTs realized the misconception of climate change in our 
society, which many people have accepted, and the PSTs' awareness had been raised after the flipped class intervention, along with item Q1. Therefore, a percentage increase in the awareness of Group 2 can be noted after the application of the proposed methodology (versus Group 1). Here, the ideas delivered in this study were not able to analyze the raising of the PSTs' awareness of climate change in an active and flipped classroom intervention.

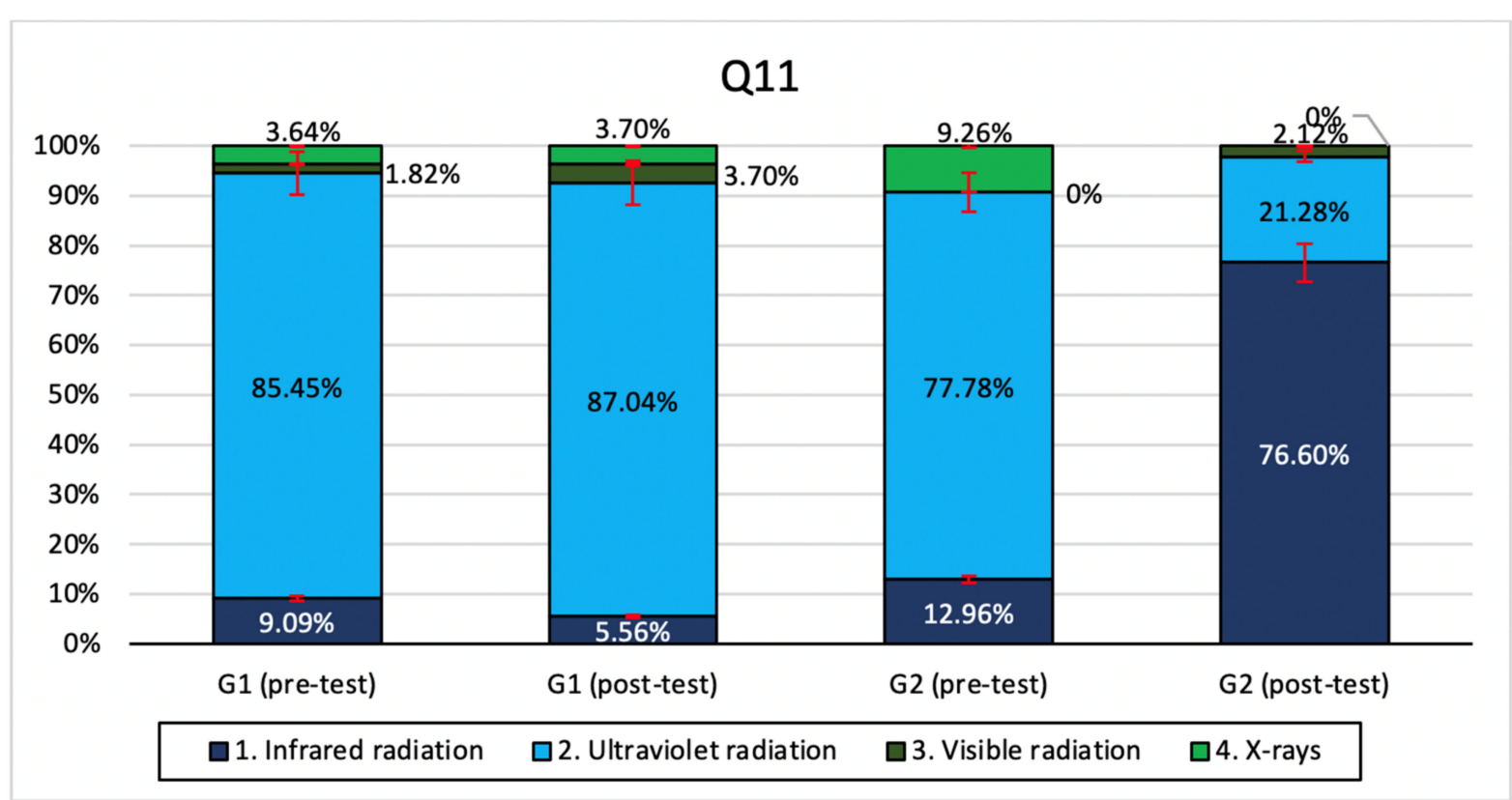

Figure 3. The results of the two groups for item Q11 ("Sunlight is formed by different types of radiation that differ in their energy. What is the type of radiation that is responsible for reiterated climate change?").

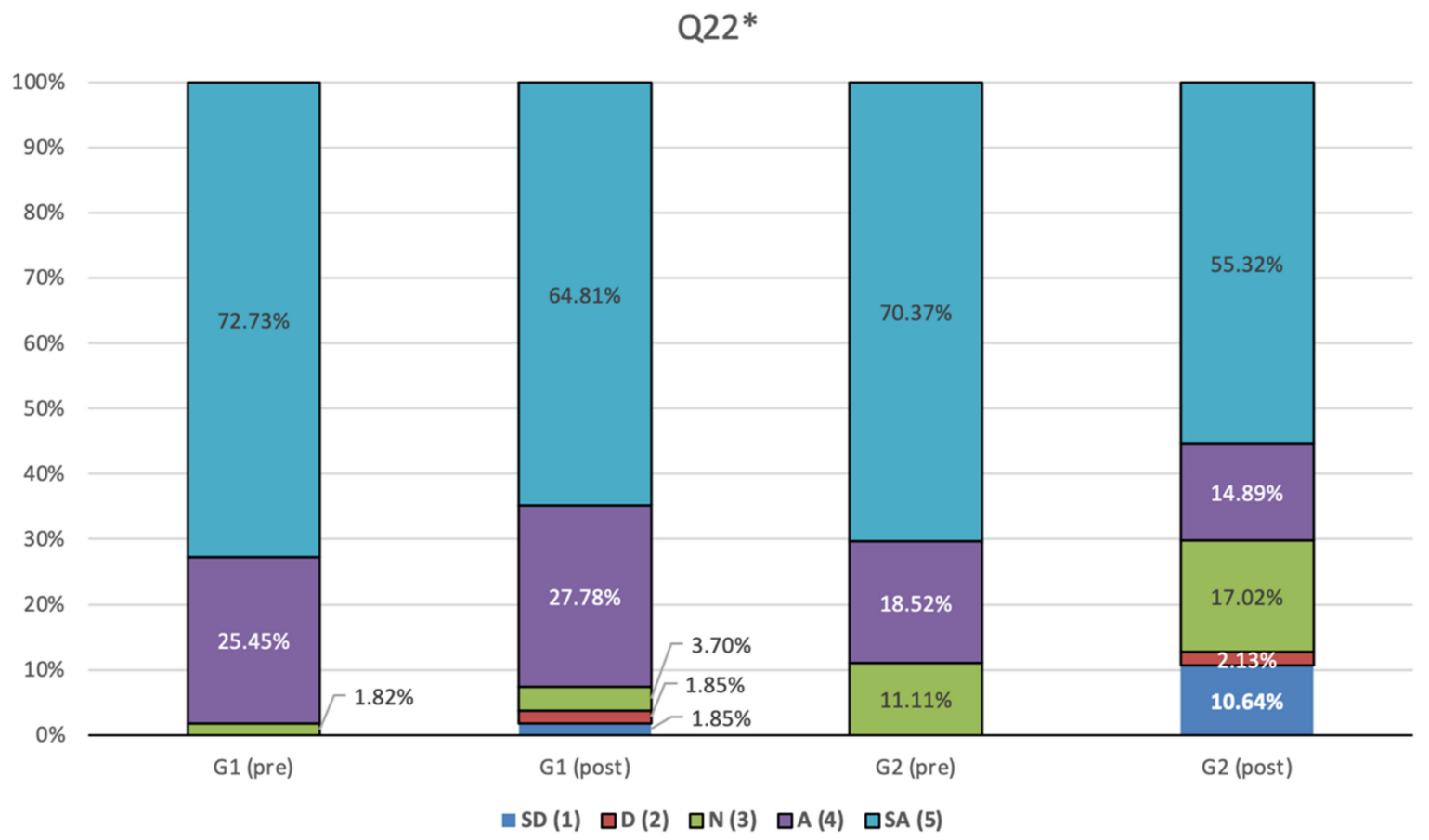

Figure 4. The results of the two groups for item Q22 ("The increase in the hole in the ozone layer implies a climatic change on Earth"), from "strongly disagree" (SD), "disagree" (D), "neutral" (N), "agree" (A), and "strongly agree" (SA). * Lower score indicates better awareness. 


\subsection{Discussion}

The results demonstrate novel information on raising the climate change awareness of PSTs through an active university learning environment. This study specified an exclusive method for class interventions and implications that consisted of active and flipped lectures and various activities. Here, during classroom time, the class used practical exercises to learn theoretical content delivered in a more student-centered environment.

Recent remarkable circumstances in Spain, together with UN, UNESCO, and DESD values, have designated the climate change issue as a noticeable worldwide occurrence [1-3,23-27]. It has been comprehensively linked to many different areas, i.e., human growth patterns, and affects land use/development, persons, and the environment [1-3]. Up to now, climate change education investments have not encountered any demand despite the acknowledgment of international policy [10-12,32,33]. Instructors are required to find out new teaching methodologies, such as the flipped classroom, that can reverse the traditional classroom method $[7,8,13]$. As the survey results have indicated (Hypothesis 1 confirmed), universities have an important position in CEE related to various challenges that our societies are confronting [9]. Research has confirmed that various CCE approaches are required and are being absorbed universally, which has led to the techniques that university education can use to address these encounters $[5,6,28,29]$. They engage with our challenges to foster investigation, advance clarification for climate change mitigation and adaptation, and give climate change a prominent position in public discussion [33,34]. Climate change in university science education can deal with the current pedagogical niche in these difficult situations. We could discover how raising the climate change awareness of PSTs will create active and flipped learning atmospheres in schools in the long-term [11,12].

Currently, in various studies, teaching climate change in university science education is considered an important concern [10-12] that can draw the attention of instructors and PSTs [10]. Along with the procedure recommended, an alternative education method, the active and flipped classroom, contributes to disseminating the concept and subjects of climate change education in university (Hypothesis 2 confirmed) [26-28]. Reversing the normal and traditional classroom, the flipped classroom methodology can move lectures out of the classroom, together with the concepts taught, through the use of various learning activities [8,13]. This alternative is considered a form of active learning and a special form of blended learning $[13,14]$. Here, the PSTs participated in various types of activities, such as active lectures, with numerous videos and other materials, which they could make into just-in-time classes while they were learning the topic $[15,16,64]$. In fact, the class activities were adjusted based on the information gathered from the PSTs and their performance $[45,46,65]$. Many scholars have claimed that a flipped classroom allows students to learn course content better than the traditional classroom [18-20,66]. Therefore, the establishment of a flipped classroom should be based not only on the social learning theory but also constructivism due to learning progression, which is attained as an active and flipped procedure from the PSTs' point of view $[15,43,67]$. Actually, on the basis of the obtained results, this approach is a more suitable environment for achieving meaningful learning, in terms of the raising of PSTs' climate change awareness, namely, when a flipped classroom was used in a science course. It is necessary to focus on more student-centered, hands-on, inquiry-based, and two-way learning scenarios [41,42,68].

Consequently, Blalock et al. confirmed that the discipline proposed could be found in fruitful results obtained [21]. Here, attitude as a reflected tendency was delineated and could provide a continuously favorable/unfavorable method with regard to a certain aim, as prearranged and advocated by the researchers like Fishbien and Ajzen [47,49,50]. As a formative aspect, we established that attitude predicts people's behavior $[38,69]$. Aside from the instructors' teaching exercises, raising awareness regarding science itself and science instruction has been acknowledged as a huge influence on PSTs' attitude, accomplishment, and predisposition to involving more science education and scientific literacy in particular $[49,51,70]$. Specifically, the instructors' awareness-raising could be connected with his/her teaching capability. Subsequently, the PSTs' confidence can be implied in a lec- 
ture on climate change in science education (Hypothesis 3 confirmed) [52,70-72]. Because of this reason, understanding PST's awareness-raising concerning climate change in science education with a flipped science course is essential in order to accomplish the professional insights and concentrated developments of PSTs (Hypotheses 1 and 2 confirmed) [52,53]. Thus, in numerous studies, it has been proposed that with better awareness-raising, instructors were much more enthusiastic in improving instructive environments [56,73]. They were much keener to offer original and innovative implementations to the class $[56,57,74]$.

\section{Conclusions and Limitation}

As to raising the climate change awareness of PSTs through an active science learning setting at university, this research offers an analysis through online survey questionnaires after two different class interventions. From the results obtained, a similar pattern was found for the selected questionnaires, such as for items Q1, Q5, Q7, Q11, and Q22, which showed a significant difference. The significance of this study is the improvement of awareness of PSTs of climate change after the flipped class intervention. Thus, the results specifying a rising awareness were improved in both groups analyzed. Particularly, Group 2 (as an experimental group) had a significant difference in pre- and post-test data. This indicates that an important percentage of the sample actively participated in the proposed methodology. Therefore, the opinions provided in the study are significant to analyzing awareness-raising using the flipped method followed.

Thus, the novel results represent that the improvement in the awareness of PSTs through a university science learning environment. In this study, an exclusive flipped method for class interventions was used. An active and flipped class consists of effective just-in-time lectures, numerous flipped videos, and other distributed materials. The PSTs were regulated during classroom time to combine practical and theoretical content, which targeted a more student-centered setting. Therefore, the outcomes obtained can considerably contribute to fill the main gaps and overcome the drawbacks of the traditional classroom method in university science education for climate change. The PSTs can achieve their professions and bring about improvements using their insight and vision to teach primary education students. Thus, the approach emphasizes that this research can deal with various instances by clarifying how climate change education might be implemented in a university science education context. With proper adaptation, it might be applied in HEIs in a future study when the earlier proposed confrontations are gotten over. As a study limitation, since the study population consisted of only PSTs, the results cannot be extrapolated to other population groups. Therefore, it is necessary to adapt it to new study groups. In addition, due to sample limitations, the study can be enriched with a bigger sample size and gender balance.

Author Contributions: Conceptualization, J.S.J., D.G.-G. and M.C.C.-N.; methodology, J.S.J., D.G.-G., M.C.C.-N., J.S.S.-C. and F.Y.-P.; software, J.S.J., D.G.-G., M.C.C.-N., J.S.S.-C. and F.Y.-P.; validation, J.S.J., D.G.-G., M.C.C.-N., J.S.S.-C. and F.Y.-P.; formal analysis, J.S.J. and D.G.-G.; investigation, J.S.J., D.G.-G., M.C.C.-N., J.S.S.-C. and F.Y.-P.; resources, J.S.J., D.G.-G., M.C.C.-N., J.S.S.-C. and F.Y.-P.; data curation, J.S.J., D.G.-G., M.C.C.-N., J.S.S.-C. and F.Y.-P.; writing-original draft preparation, J.S.J., D.G.-G., M.C.C.-N., J.S.S.-C. and F.Y.-P.; writing-review and editing, J.S.J. and D.G.-G.; visualization, J.S.J., D.G.-G., M.C.C.-N., J.S.S.-C. and F.Y.-P.; supervision, J.S.J. and D.G.-G.; project administration, J.S.J. and D.G.-G. All authors have read and agreed to the published version of the manuscript.

Funding: The authors gratefully acknowledge the Consejerería de Economía, Ciencia y Agenda Digital de la Junta de Extremadura y Fondo Europeo de Desarrollo Regional (FEDER)—Project IB18004, which support this research possible.

Institutional Review Board Statement: The study was conducted according to the guidelines of the Declaration of Helsinki, and ap-proved by Ethics Committee of University of Extremadura (ref. 94/2018).

Informed Consent Statement: Not applicable.

Data Availability Statement: Data available on request.

Conflicts of Interest: The authors declare no conflict of interest. 


\section{Appendix A}

Table A1. Survey questionnaires for raising awareness in order to improve climate change education in university science education for PSTs.

\begin{tabular}{|c|c|c|c|}
\hline Items of Question & Type & Choice & Significant Difference \\
\hline $\begin{array}{l}\text { Q1. Climate change proposed } \\
\text { for years by the community of } \\
\text { scientists is an invention to } \\
\text { take better care of the planet. }\end{array}$ & Five-point Likert-type & 1 to 5 . & Yes \\
\hline $\begin{array}{l}\text { Q2. Climate change is a } \\
\text { significant and lasting change of } \\
\text { local or global weather patterns; } \\
\text { the causes could be ... }\end{array}$ & $\begin{array}{l}\text { Multiple selection } \\
\text { (Max. 3) }\end{array}$ & $\begin{array}{l}\text { Variations in the energy received from } \\
\text { the Sun, volcanic eruptions, ocean } \\
\text { circulation, biological processes, and } \\
\text { other causes. } \\
\text { The use of fertilizers and fuels. } \\
\text { The actions of humans. }\end{array}$ & No \\
\hline $\begin{array}{l}\text { Q3. What factors are the } \\
\text { biggest causes of the current } \\
\text { climate change? }\end{array}$ & $\begin{array}{l}\text { Multiple selection } \\
\text { (Max. 11) }\end{array}$ & $\begin{array}{l}\text { Volcanic activity. } \\
\text { The use of vehicles. } \\
\text { The industry. } \\
\text { Renewable energy. } \\
\text { Deforestation. } \\
\text { Use of fertilizers. } \\
\text { The burning of fossil fuels. } \\
\text { The production of food and many other } \\
\text { goods and services that we consume } \\
\text { every day. } \\
\text { Nuclear power plants. } \\
\text { Landfill. } \\
\text { Cattle. } \\
\text { CFCs. }\end{array}$ & No \\
\hline
\end{tabular}

In the number of inhabitants.

Population influences on climate

Q4. To what extent does the population influence climate change?

Multiple choice (Max. 6)

Q5. Of the following gases, which one indicates the three most responsible gases for climate change. change through the process of industrialization and deforestation.

Global warming is not linked to human

No

actions, and it depends on the sun,

clouds, wind, on which the weather always depends.

Oxygen.

Carbon dioxide.

Methane.

Water steam.

Yes

CFCs.

Ozone.

Thawing of the polar caps.

Climate warming.

Increase in the average temperature of the atmosphere.

Increased storms and rainfall.

Q6. Of the following phenomena, which ones can be caused by climate change.
Multiple selection (Max. 10)
Increase in droughts.

Increase in the frequency of

No

earthquakes and volcanic eruptions.

Lack of water.

Decrease in biodiversity.

Increased cases of skin cancer.

Thinning of the ozone layer. 
Table A1. Cont.

\begin{tabular}{|c|c|c|c|}
\hline Items of Question & Type & Choice & Significant Difference \\
\hline $\begin{array}{l}\text { Q7. Do you think that climate } \\
\text { change can negatively affect } \\
\text { the planet? }\end{array}$ & Multiple choice & $\begin{array}{l}\text { No, it is a natural phenomenon. } \\
\text { Yes, the increase in temperature causes } \\
\text { irreparable damage to the planet. } \\
\text { We are not sure it affects the planet. } \\
\text { It would affect, but it does not matter } \\
\text { because these problems have occurred } \\
\text { in the geological history of the Earth } \\
\text { and life has always continued. }\end{array}$ & Yes \\
\hline $\begin{array}{l}\text { Q8. Which of these } \\
\text { environmental problems do } \\
\text { you consider to be the most } \\
\text { important at the moment? }\end{array}$ & Multiple choice & $\begin{array}{l}\text { Climate change. } \\
\text { Atmospheric pollution. } \\
\text { Pollution of the oceans. } \\
\text { Illegal trade in animals. } \\
\text { Destruction of forests and rainforests. } \\
\text { Extinction of animal species. } \\
\text { I do not consider any major } \\
\text { environmental problems. }\end{array}$ & No \\
\hline
\end{tabular}

Charge the mobile.

Shower with hot water.

Dry your hair with a hair dryer.

Q9. From the following list of activities in your daily life, please select those that you think may contribute to climate change.
Multiple selection (Max. 12)
Ride a bike.

Drive to the institute.

Use air conditioning.

Listen to the music on the phone.

No

Take a motorcycle ride.

Light the stove.

Play with the game console.

Download files from the Internet.

Play football.
Q10. Do you take any action individually to reduce climate change?
Q11. Sunlight is formed by different types of radiation that differ in their energy. What is the type of radiation that is responsible for climate change?

Q12. What factor has caused the temperature rise in recent years?

Multiple choice

Q13. The greenhouse effect is
Open-ended answer

Text.

No

Infrared radiation

Ultraviolet radiation.

Visible radiation.

Yes

$\mathrm{X}$-rays.

The increase in the concentration of greenhouse gases in the atmosphere. It should be checked, as this issue is not defined in the short term but in the long term.

No

The variation in solar radiation that the

Earth receives.

None of the above.

A natural phenomenon that allows life on Earth by maintaining a suitable temperature.

A phenomenon that has been increased by human activities.

It is produced by gases, called atmosphere that prevent part of the energy from being returned.

All of the above. 
Table A1. Cont.

\begin{tabular}{|c|c|c|c|}
\hline Items of Question & Type & Choice & Significant Difference \\
\hline $\begin{array}{l}\text { Q14. What relationship does } \\
\text { the greenhouse effect have } \\
\text { with climate change? }\end{array}$ & Multiple choice & $\begin{array}{l}\text { None. } \\
\text { It is only relevant in some countries. } \\
\text { If the greenhouse effect increases, the } \\
\text { temperature of the Earth increases. }\end{array}$ & No \\
\hline $\begin{array}{l}\text { Q15. Among the gases } \\
\text { previously mentioned (Q5), } \\
\text { which one indicates the } \\
\text { greatest greenhouse effect. }\end{array}$ & Open-ended answer & Text. & No \\
\hline $\begin{array}{l}\text { Q16. Which gas has } \\
\text { significantly increased its } \\
\text { concentration in recent years } \\
\text { and is considered the main } \\
\text { cause of the increase in the } \\
\text { greenhouse effect? }\end{array}$ & Multiple choice & $\begin{array}{l}\text { Ozone (O3). } \\
\text { Methane (CH4). } \\
\text { Chlorofluorocarbons (CFCs). } \\
\text { Carbon dioxide (CO2). }\end{array}$ & No \\
\hline $\begin{array}{l}\text { Q17. From what source of } \\
\text { information have you } \\
\text { obtained everything you } \\
\text { know about climate change? }\end{array}$ & $\begin{array}{l}\text { Multiple selection } \\
\text { (M.ax 5) }\end{array}$ & $\begin{array}{l}\text { Friends and family. } \\
\text { Scientific articles. } \\
\text { Newspaper. } \\
\text { Teachers. } \\
\text { Textbooks. }\end{array}$ & No \\
\hline
\end{tabular}

Q18. Do you know of any event, agreement, summit, or prize that has to do with climate change? You can Open-ended answer Text. No provide details on what you know about it.

Q19. Do you think we all have equal responsibility for the problem generated by climate change?

Q20. Do you think the consequences of climate change will affect us all Open-ended answer Text. No equally?

Q21. Have you participated in any way in the mobilizations on climate change?

Q22. The following statement: "The increase in the hole in the ozone layer implies a climatic change on Earth."

\section{References}

1. Brouziyne, Y.; Abouabdillah, A.; Hirich, A.; Bouabid, R.; Zaaboul, R.; Benaabidate, L. Modeling sustainable adaptation strategies toward a climate-smart agriculture in a Mediterranean watershed under projected climate change scenarios. Agric. Syst. 2018, 162, 154-163. [CrossRef]

2. Ministry of Environment. Informe Evaluación Preliminar General de los Impactos en España por Efecto del Cambio Climático; UCLM: Madrid, Spain, 2005.

3. Jeong, J.S.; González-Gómez, D.; Cañada-Cañada, F. Prioritizing elements of science education for sustainable development with the MCDA-FDEMATEL method using the flipped e-learning scheme. Sustainability 2019, 11, 3079. [CrossRef]

4. Godemann, J.; Herzig, C.; Moon, J. Approaches to Changing the Curriculum. Presentation Given on the ISIBS Workshop e Session II; University of Nottingham: Nottingham, UK, 2011.

5. Monroe, M.; Plate, R.R.; Oxarart, A.; Bowers, A.; Chaves, W.A. Identifying effective climate change education strategies: A systematic review of the research. Environ. Educ. Res. 2017, 25, 791-812. [CrossRef] 
6. Hindley, A.; Wall, T. A unifying, boundary crossing approach to developing climate literacy. In Implementing Sustainability in the Curriculum of Universities: Teaching Approaches, Methods, Examples and Case Studies; Leal Filho, W., Ed.; Springer: London, UK, 2017; pp. 263-278.

7. Buli-Fabregá, M.; Martínez, M.; Ruiz, N.; Leal, W. Flipped classroom as an active learning methodology in sustainable development curricula. Sustainability 2019, 11, 4577. [CrossRef]

8. Strayer, J.F. How learning in an inverted classroom influences cooperation, innovation and task orientation. Learn. Environ. Res. 2012, 15, 171-193. [CrossRef]

9. Rusinko, C.A. Integrating sustainability in management and business education. Acad. Manag. Learn. Educ. 2010, 9, 507-519.

10. Bynoe, P.; Simmons, D. 'Curriculum Audit of Infusion of Climate Change Education into the Science and Social Studies School's Curricula (Grades 1 to 6)', Report Submitted to National Centre for Education Resources Development; National Centre for Education Resources Development: Georgetown, DC, USA, 2011.

11. David, J.H.; Maki, A. Climate change belief, sustainability education, and political values: Assessing the need for higher-education curriculum reform. J. Clean. Prod. 2019, 228, 1157-1166.

12. Molthan-Hill, P.; Worsfold, N.; Nagy, G.J.; Leal Filho, W.; Mifsud, M. Climate change education for universities: A conceptual framework from an international study. J. Clean. Prod. 2019, 226, 1092-1101. [CrossRef]

13. Tucker, B. The flipped classroom. Online instruction at home frees class for learning. Educ. Next 2012, 12, 82-83.

14. Blair, E.; Maharaj, C.; Primus, S. Performance and perception in the flipped classroom. Educ. Info. Technol. 2016, 21, 1465-1482. [CrossRef]

15. Sams, A.; Bergmann, J. Flip your students' learning. Technol. Rich. Learn. 2014, 70, 16-20.

16. González-Gómez, D.; Jeong, J.S. EdusciFIT: A computer-based blended and scaffolding toolbox to support numerical concepts for flipped science education. Educ. Sci. 2019, 9, 116.

17. Kapoun, P.; Milková, A. MLearning-efficient support of natural science education. Glob. J. Inf. Technol. 2014, 4, 114-119.

18. Yllana-Prieto, F.; Jeong, J.S.; González-Gómez, D. An online-based edu-escape room: A comparison study of a multidimensional domain of PSTs with flipped sustainability-stem contents. Sustainability 2021, 13, 1032. [CrossRef]

19. Robin, A.L. Behavioral instruction in the college classroom. Rev. Educ. Res. 1976, 46, 313-354. [CrossRef]

20. Brewer, R.; Movahedazarhouligh, S. Successful stories and conflicts: A literature review on the effectiveness of flipped learning in higher education. J. Comput. Assist. Learn. 2018, 34, 409-416. [CrossRef]

21. Blalock, C.L.; Lichtenstein, M.J.; Owen, S.; Pruski, L.; Marshall, C.; Toepperwein, M. In pursuit of validity: A comprehensive review of science attitude instruments 1935-2005. Int. J. Sci. Educ. 2008, 30, 961-977. [CrossRef]

22. Tschannen-Moran, M.; Woolfolk-Hoy, A. Teacher efficacy: Capturing an elusive construct. Teach. Teach. Educ. 2001, 17, 783-805. [CrossRef]

23. Charalambous, C.; Philippou, G. Teachers' concerns and efficacy beliefs about implementing a mathematics curriculum reform: Integrating two lines of inquiry. Educ. Stud. Math. 2010, 75, 1-21. [CrossRef]

24. Bushell, S.; Buisson, G.S.; Workmann, M.; Colley, T. Strategic narratives in climate change: Towards a unifying narrative to address the action gap on climate change. Energy Res. Soc. Sci. 2017, 28, 39-49. [CrossRef]

25. UNESCO. UN Decade of Education for Sustainable Development, 2005-2014: The DESD at a Glance; UNESDOC: New York, NY, USA, 2005.

26. Jeong, J.S.; Ramírez-Góomez, Á. Development of a web graphic model with fuzzy-decision-making Trial and Evaluation Laboratory/Multi-criteria-Spatial Decision Support System (F-DEMATEL/MC-SDSS) for sustainable planning and construction of rural housings. J. Clean. Prod. 2018, 199, 584-592. [CrossRef]

27. Sterling, S. Sustainable Education: Re-Visioning Learning and Change; Schumacher Briefings; ERIC; Green Books: Totnes, UK, 2001.

28. Leicht, A.; Heiss, J.; Byun, W.J. Issues and Trends in Education for Sustainable Development; UNESCO Publishing: Paris, France, 2018.

29. Gadotti, M. ESD and education for all: Synergies and potential conflicts. Int. Rev. Educ. 2010, 56, 221-234. [CrossRef]

30. Stephens, J.; Hernandez, M.; Roman, M.; Graham, A.; Scholz, R. Higher education as a change agent for sustainability in different cultures and contexts. Int. J. Sustain. High. Educ. 2008, 9, 317-338. [CrossRef]

31. Leal Filho, W.; Pallant, E.; Enete, A.; Richter, B.; Brandli, L.L. Planning and implementing sustainability in higher education institutions: An overview of the difficulties and potentials. Int. J. Sustain. Dev. World Ecol. 2018, 25, 713-721. [CrossRef]

32. UNESCO. UNESCO at COP23. Climate Change Education; UNESDOC: New York, NY, USA, 2017.

33. UNFCC. Paris Agreement; United Nations Framework Convention on Climate Change: New York, NY, USA, 2015.

34. UNCC: Learn. The One UN Climate Change Learning Partnership. Integrating Climate Change in Education at Primary and Secondary Level; UNITAR: Geneva, Switzerland, 2013.

35. Filho, W.L. Climate Change Research at Universities Addressing the Mitigation and Adaptation Challenges; Springer: Berlin, Germany, 2017.

36. Leal Filho, W.; Shiel, C.; Paço, A. Implementing and operationalising integrative approaches to sustainability in higher education: The role of projectoriented learning. J. Clean. Prod. 2016, 133, 126-135. [CrossRef]

37. Leal Filho, W. Climate Change at Universities. Results of a World Survey. In Universities and Climate Change: Introducing Climate Change to University; Leal Filho, W., Ed.; Springer: Berlin, Germany, 2010; pp. 1-19.

38. Bushell, S.; Workmann, M.; Colley, T. Towards a Unifying Narrative for Climate Change-Grantham Briefing Paper 18; Grantham Publications: London, UK, 2016. 
39. Jeong, J.S.; González-Gómez, D. Adapting to PSTs' pedagogical changes in sustainable mathematics education through flipped E-Learning: Ranking its criteria with MCDA/F-DEMATEL. Mathematics 2020, 8, 858. [CrossRef]

40. Eneroth, C. E-Learning for Environment. Improving e-Learning as a Tool for Cleaner Production Education. Licentiate Dissertation, Lund University, Lund, Sweden, 2010.

41. Gutiérrez Gallego, J.A.; Naranjo Gómez, J.M.; Jaraíz-Cabanillas, F.J.; Ruiz Labrador, E.E.; Jeong, J.S. A methodology to assess the connectivity caused by a transportation infrastructure: Application to the high-speed rail in Extremadura. Case Stud. Transp. Policy 2015, 3, 392-401. [CrossRef]

42. Van Aalderen-Smeets, S.I.; van der Molen, J.H.W. Improving primary teacher' attitudes toward science by attitude-focused professional development. J. Res. Sci. Teachol. 2015, 52, 710-734. [CrossRef]

43. Hill, J.R.; Song, L.; West, R.E. Social learning theory and webbased learning environments: A review of research and discussion of implications. Am. J. Distance Educ. 2009, 23, 88-103. [CrossRef]

44. Bergmann, J.; Sams, A. Flipped Learning: Maximizing Face Time; Training \& Development: New York, NY, USA, 2014.

45. Formica, S.P.; Easley, J.L.; Spraker, M.C. Transforming common-sense beliefs into Newtonian thinking through just-in- time teaching. Phys. Educ. Res. 2010, 6, 1-7. [CrossRef]

46. Moraros, J.; Islam, A.; Yu, S.; Banow, R.; Schindelka, B. Flipping for success: Evaluating the effectiveness of a novel teaching approach in a graduate level setting. BMC Med. Educ. 2015, 15, 27. [CrossRef] [PubMed]

47. Fishbein, M.A.; Ajzen, I. Belief, Attitude, Intention and Behaviour: An Introduction to Theory and Research; Addison-Wesley: Reading, MA, USA, 1975.

48. Jones, M.G.; Leagon, M. Science Teacher Attitudes and Beliefs: Reforming Practice. In Handbook of research on science education; Lederman, N.G., Abell, S.K., Eds.; Routledge: New York, NY, USA, 2014; pp. 830-847.

49. Ajzen, I. The theory of planned behavior. Organ. Behav. Human Decis. Pro. 1991, 50, 179-211. [CrossRef]

50. Fritsche, I.; Barth, M.; Jugert, I. A social identity model of pro-environmental action (SIMPEA). Psychol. Rev. 2017, 125, 245-269. [CrossRef]

51. Avery, L.M.; Meyer, D.Z. Teaching science as science is practice: Opportunities and limits for enhancing preservice elementary teachers' self-efficacy for science and science teaching. Sch. Sci. Math. 2012, 112, 395-409. [CrossRef]

52. Oppermann, E.; Brunner, M.; Anders, Y. The interplay between preschool teachers' science self-efficacy beliefs, their teaching practices, and girls' and boys' early science motivation. Learn. Individ. Differ. 2019, 70, 86-99. [CrossRef]

53. Kazempour, M. I can't teach science! A case study of an elementary pre-service teacher's intersection of science experience, beliefs, attitude, and self-efficacy. Int. J. Environ. Sci. Educ. 2014, 9, 77-96.

54. Olakanmi, E.E. The effects of a flipped classroom model of instruction on students' performance and attitudes towards chemistry. J. Sci. Educ. Technol. 2017, 26, 127-137. [CrossRef]

55. Saçkes, M.; Flevares, L.M.; Gonya, J.; Trundle, K.C. Preservice early childhood teachers' sense of efficacy for integrating mathematics and science: Impact of a methods course. J. Early Child Teach. Educ. 2012, 33, 349-364.

56. Jeong, J.S.; González-Gómez, D.; Cañada-Cañada, F. Enhancing science self-efficacy and attitudes of Pre-Service Teachers (PST) through a flipped classroom learning environment. Interact. Learn. Environ. 2019, 1-12. [CrossRef]

57. Jeong, J.S.; González-Gómez, D.; Conde-Núñez, M.C.; Gallego-Picó, A. Examination of students' engagement with R-SPQ-2F of learning approach in flipped sustainable science course. J. Baltic Sci. Educ. 2019, 18, 880-891. [CrossRef]

58. Roach, T. Student perceptions toward flipped learning: New methods to increase interaction and active learning in economics. Int. Rev. Econ. Educ. 2014, 17, 74-84. [CrossRef]

59. Etxeberria, J.; Tejedor, F.J. Descriptive Data Analysis in Education; La Muralla: Madrid, Spain, 2005.

60. Jeong, J.S.; González-Gómez, D.; Cañada-Cañada, F. How does a flipped classroom course affect the affective domain toward science course? Interact. Learn. Environ. 2019, 1-13. [CrossRef]

61. Ghasemi, A.; Zahediasl, S. Normality tests for statistical analysis: A guide for non-statisticians. Int. J. Endocrinol. Metab. 2012, 10, 486-489. [CrossRef] [PubMed]

62. Harpe, S.E. How to analyze Likert and other rating scale data. Curr. Pharma. Teach. Learn. 2015, 7, 836-850. [CrossRef]

63. Sevki Ayvaci, H.; Ozbek, D. The effect of documentary films on preservice science teachers' views of nature of science. J. Sci. Learn. 2019, 2, 97-107. [CrossRef]

64. Biggs, J.; Tang, C. Teaching for Quality Learning at University. The Society for Research into Higher Education; Open University Press: Cambridge, UK, 2007.

65. Mason, G.S.; Rutar, T.S.; Cook, K.E. Comparing the effectiveness of an inverted classroom to a traditional classroom in an upper-division engineering course. Educ. IEEE Trans. 2013, 56, 430-435. [CrossRef]

66. Kim, M.K.; Kim, S.M.; Khera, O.; Getman, J. The experience of three flipped classrooms in an urban university: An exploration of design principles. Int. Higher Educ. 2014, 22, 37-50. [CrossRef]

67. Jeong, J.; González-Gómez, D. A web-based tool framing a collective method for optimizing the location of a renewable energy facility and its possible application to sustainable STEM education. J. Clean. Prod. 2020, 251, 119747. [CrossRef]

68. Hinojo-Lucena, F.; Mingorance-Estrada, Á.; Trujillo-Torres, J.; Aznar-Díaz, I.; Cáceres Reche, M. Incidence of the flipped classroom in the physical education Students' academic performance in university contexts. Sustainability 2018, 10, 1334. [CrossRef]

69. Schönfelder, M.; Bogner, F. Between science education and environmental education: How science motivation relates to environmental values. Sustainability 2020, 12, 1968. [CrossRef] 
70. Osborne, J.; Simon, S.; Collins, S. Attitudes towards science: A review of the literature and its implications. Int. J. Sci. Educ. 2003, 25, 1049-1079. [CrossRef]

71. Tune, J.D.; Sturek, M.; Basile, D.P. Flipped classroom model improves graduate student performance in cardiovascular, respiratory, and renal physiology. Adv. Physiol. Educ. 2013, 11, 57-77. [CrossRef] [PubMed]

72. Davies, R.S.; Dean, D.L.; Ball, N. Flipping the classroom and instructional technology integration in a college-level information systems spreadsheet course. Educ. Tech. Res. Dev. 2013, 61, 563-580. [CrossRef]

73. Bogner, F.X.; Wiseman, M. Adolescents' attitudes towards nature and environment: Quantifying the 2-MEV model. Environmentalist 2006, 26, 247-254. [CrossRef]

74. Lovelace, M.; Brickman, P. Best practices for measuring students' attitudes toward learning science. CBE Life Sci. Educ. 2013, 12, 606-617. [CrossRef] [PubMed] 